\title{
The role of international development strategies in making regional development policies: Hokkaido as a case study
}

During the past decades, national governments and international institutions have both searched for ways to equalise disparities and revitalise lagging regions. Although ideas and examples of the most effective ways to achieve these goals originate in various places, their influence is inclined to permeate elsewhere. Therefore, the processes involved in policy transfers are highly relevant from the perspective of regional development. This study approaches these processes through the case study of post-war Hokkaido and pays special attention to the role of three international development strategies: the Tennessee Valley Authority model, the Growth Pole Theory and the Industrial Cluster Theory. As a result, this research shows the wide variety of agents involved in policy transfer, analyses the processes of incorporating exogenous ideas into regional development polices and demonstrates the variety of sources from which different agents can draw lessons.

Keywords: policy transfer, regional development, development strategies, Hokkaido 


\section{Introduction}

Because some regions benefit more from - or cope better with - changes in the global redistribution of work and production than others, national governments and international institutions have both continued to search for ways to equalise disparities or revitalise lagging regions in other parts of the world. The aims of these policy measures have usually been to create and redistribute economic growth and eliminate chronic regional disparities that prevent the attainment of national policy objectives (Armstrong \& Taylor, 2000; Pike et al., 2007). Ideas regarding the most effective means of achieving these goals have originated in various places, but they have also been inclined to spread. Therefore, the processes involved in policy transfer (i.e., processes in which knowledge about policies, administrative arrangements, institutions and ideas in one political setting are used in the development of policies, administrative arrangements, institutions and ideas in another) are also highly significant in the context of regional development policy (Dolowitz \& Marsh, 2000; Benson \& Jordan, 2011).

Research regarding policy transfer has increased greatly since the late 1990s and it has been shown that occurrences of policy transfer have increased during recent decades - due to technological advances and occasional pressure originating from various international organisations, for example (Dolowitz \& Marsh, 2000). However, this is neither a new nor geographically restricted phenomenon. In fact, the motivation to study Hokkaido is drawn from an observation that the majority of policy transfer studies concentrate on the empirical context of Europe and the United States. Huck-ju Kwon (2009) has argued that policy learning and transfer can be considered missing elements in the study of East Asia’s developing countries.

Hokkaido can be described as a peripheral region, given its position within Japan and its location in north-eastern Asia. However, international models and agents have played an important role in the 150-year process during which the island, formerly known as Ezochi, has been incorporated into and developed as a part of modern Japan. This process can be and has been described in terms ranging from colonisation, subordination or civilisation to modernisation or even revitalisation depending on the standpoint taken (Mason, 2012; Sasaki, 2015). Nevertheless, the many years that Hokkaido has been the subject of continuous state-led development activities and the scope of these activities make Hokkaido an interesting subject for any study whose focus is regional development policies.

This article considers the regional development policies implemented in Hokkaido during the post-war era with two objectives in mind. First, the article contributes to the study of the policy transfer phenomenon through a case that focuses on human agency and on a relatively poorly known geographic entity, especially to those that do not read Japanese. Second, the study adds to a body of research that seeks to explain the content of, and processes through which, the post-war regional development policies of Hokkaido came into being through elaborating the role of international development strategies. The Tennessee Valley Authority (TVA) model, the Growth Pole and Industrial Cluster Theories are identified as useful examples through which many different aspects of policy transfer can be elaborated upon. The analysis of the role of these strategies in three policy-making processes form the main body of this article. The analysis follows a brief introduction to conceptual foundations and is followed by concluding remarks. Although based on an analysis of publicly available written documents, this study additionally utilises other methods to gather data. In addition to conducting interviews and studying archival sources, the author participated as an observer in a number of cluster-related events in the mid-2000s.

In order to increase the understanding of policy choices made in relation to the development of Hokkaido, reference is made to local adaptations to the same strategies in the northern parts of Nordic countries. These regions are all peripheral parts of relatively wealthy and politically stable democratic countries that have simultaneously followed market-oriented capitalism and accepted state interventionism. Distinctive differences commonly arise between these northern regions and the central or capital regions of individual countries.

\section{Policy transfer: who, why, from where}

Although this study recognises the existence of a wide variety of interconnected and overlapping concepts, such as lessondrawing, policy convergence and policy diffusion, it focuses on policy transfer and borrows from attempts by David P. Dolowitz and David Marsh (2000) to place this process within a conceptual framework. The model of Dolowitz and Marsh is based upon questions, three of which are accorded special focus in this study. These are questions concerning the identification of key agents involved in policy transfer, their reasons for engaging in policy transfer and the sources they draw lessons from. The conscious decision to emphasise agents and agency - understood as the capacity to act and the experience of acting, the ability to bring about effects and exert or exercise power - is based on assumptions concerning the nature of decision-making processes. Despite the existence of structural factors, such as organisational culture or standard patterns of behaviour, it is thought that not being able to achieve stipulations characteristic of the classical rational 
decision model (strategic thinking, bargaining, compromise, beliefs and values - all typical of human decision-making) may play an even more remarkable role in decision-making processes. For an overview, see Charles E. Lindblom (1968) and Graham Allison and Philip Zelikow (1999).

The changing context of development in Hokkaido renders highly relevant the question about the nature of transfer - that is, whether it is voluntary (where it is motivated, for example, by dissatisfaction with the status quo and/or by the presumption of the existence of a model that is even better than the model applied currently) or coercive (where new policies are introduced, based, for example, on the demands or pressure from external agents, international competition or public opinion). One should remember that, although Japan has for decades been recognised as a fully-sovereign state with membership in all important international governmental organisations, it was a country defeated and under foreign occupation between 1945 and 1952. It is also important to pay attention to shifts in dependence upon and relations between Hokkaido's development policies and national policies. After all, policymakers do not seek only to learn from foreign counties; policy transfer also happens at subnational levels.

During the early phase of theory development, previous policy successes and failures within the domestic context or foreign political systems were recognised by policymakers as sources of innovation for new policies. However, as studies accumulated, alternative learning venues were identified. Thus, the role of NGOs, think tanks and intergovernmental bodies was acknowledged alongside peer-to-peer transfer between national governments (Benson \& Jordan, 2011). This study shows that, although these conclusions have often been based on research concentrating on recent developments, the role of alternative learning venues can also be seen historically. Although already introduced in literature relating to policy transfer, it is worthwhile to elaborate on two points. The process of policy transfer is emphasised, but it is not described as the sole explanation for any policy development. Furthermore, the search for and application of ideas and practices across different types of boundaries is not necessarily deliberate, conscious or goal-oriented. Rather, it can be unsystematic, unstructured or an outcome of random exposure to information (Dolowitz \& Marsh, 2000; Dolowitz \& Medearis, 2009).

\section{TVA: public debate on the ideal model of regional development}

The TVA was part of the New Deal programme. Its original purpose in 1933 was to address the Tennessee Valley's most important issues in energy, environmental stewardship and economic development. The TVA was supposed to be a new kind of corporation equipped with governmental powers and balancing the interests of industry, agriculture, transportation, resource development, conservationists and social planners. Ideally, the TVA was also there to promote grass-roots participation in the planning and execution of development projects. The TVA had been known in pre-war Japan and the comprehensive war-time perspectives on resource planning paved the way for the model to become popular during the immediate post-war period (Dinmore, 2013; Internet 3).

The TVA was often mentioned in discussions concerning the development of Hokkaido in the late 1940s and early 1950s. However, existing research contains conflicting interpretations concerning the role, and the importance and objectives of different agents. According to a study by Eric Dinmore (2013), the TVA served as a policy model for post-war intellectuals and policymakers seeking to manage and harness Japan's hydrosphere as a strategic resource for socioeconomic development. The TVA also served as a key inspiration for the 1950 Law on Comprehensive National Land Development, which laid the foundations for comprehensive post-war development and emphasised large-scale hydrologic projects and other public works.

In Dinmore's analysis, progressive Japanese economic thinkers such as Shigeto Tsuru, who held positions or had contacts with the Economic Stabilization Board (ESB), and certain occupation authorities, such as Edward A. Ackerman, are recognised as actors promoting the TVA in Japan. Tsuru led the TVA Studies Discussion Group, which maintained contact with the TVA's headquarters in Knoxville and published a monthly bulletin on TVA studies in Japanese. Some of the Japanese experts were even able to visit the TVA sites in the early 1950s with funding provided by the United States. These Tokyo-centred resource analysts provided the post-war Japanese with authoritative advice not exclusively in relation to dams, but also to other forms of development. Furthermore, Dinmore emphasises the important role of New Deal thinking in post-war Japanese state-centric developmentalism. What his article does not mention, however, is Hokkaido; it introduces neither the Hokkaido Development Law enacted in 1950, nor the Hokkaido Development Agency (HDA) established in 1950, nor the Hokkaido Development Bureau (HDB) founded in 1951.

The birth of a development system in Hokkaido that differed from others elsewhere in Japan forms the very nucleus of a study by Shüji Koiso (2003). According to Koiso's analysis, the New Dealers - who occupied central positions within the Government Section, which held significant authority inside the General Headquarters Supreme Commander for Allied Powers $(\mathrm{GHQ} / \mathrm{SCAP})$ - did not promote but, against all 
expectations, opposed the comprehensive development philosophy of the TVA when negotiations took place in regard to the structuring of Hokkaido's post-war development. Hokkaido-based agents enthusiastically referred to the TVA as a model that could be utilised when reconstructing Hokkaido's development system. Nevertheless, they faced opposition from the occupying authorities and central government.

There are two points worth noting in relation to these contradictory arguments. It is necessary to realise that these studies refer to different discussions. Dinmore analyses a process in which the TVA was debated as a model for the building of hydroelectric infrastructure and the utilisation of Japan's water resources. Koiso's focus is on the process of establishing an institution that could lead different types of publicly funded development projects in Hokkaido. The recognition of separate discussions allows different agents' attitudes toward the idea of using the TVA as a model to be understood better. Although the New Dealers inside the GHQ/SCAP could welcome the TVA as a model for the utilisation of water resources, they could at the same time reject the TVA as a model for development in Hokkaido. The GHQ/SCAP persistently opposed the idea that Hokkaido's special characteristics would necessitate the establishment of a special development organisation, the authority of which would not be limited to a branch of administration, but to the borders of one territorial entity within the country. Eventually, the occupying authorities' permission to form the HDA and the HDB at the end of the occupation reflected the readiness of GHQ/SCAP to allow the Japanese government to amend existing laws and ordinances on the proviso that they did not violate the ordinances of the occupiers (Banno, 2003; Saunavaara, 2014).

The progressive or left-wing side of the political spectrum is well represented when the promoters of the TVA in Japan are listed. For example, in addition to the ESB, which gained power under the premiership of socialist Tetsu Katayama, the socialist governor of Hokkaido, Toshifumi Tanaka, also talked eagerly about the TVA. The politically inexperienced Tanaka was elected in 1947, when the electorate could vote in gubernatorial elections for the first time. Tanaka familiarised himself with the ideas of the TVA in the autumn of 1949 and a philosophy of comprehensive development - with the ultimate objective not being that of resource development, but of improving people's everyday lives in Hokkaido - became an inseparable part of his political argument (Okuda, 1956; Takahashi, 1982; Banno, 2003). Based on his optimism regarding the TVA, a similarity can be seen between Tanaka and those experts in Tokyo that were either unconcerned with - or unaware of - some of the actual features of the TVA, such as electric power generation to the clear benefit of industrial giants or the problems that existed regarding the inclusion of local authorities in decision-making (Dinmore, 2013). The links between Tanaka's administration and the ESB seem to have been established through the director of Hokkaido's Forest Office, whose allies in the ESB assisted the Tanaka administration when it negotiated with central government on the establishment of the electric power development programme in Hokkaido (Takahashi, 1982). However, was it inevitable that the TVA model was promoted by the left wing of Hokkaido's political spectrum?

If one looks at Finland, which was in many ways lagging behind Norway and Sweden in the early 1950s, one can also find demands for a comprehensive, publicly funded, national program to benefit the northern part of the country. The main features of the program included the establishment of hydroelectric power, industrialisation and utilisation of local natural and mineral resources. Industrialisation was considered to be a process that could proceed concurrently with the development of local agriculture. The most prominent figure promoting these ideas was Prime Minister Urho Kekkonen, who represented the Agrarian League (The Centre Party of Finland since 1965) and later served as president of Finland for many years. Although the TVA model did not enjoy the same public recognition in Finland as it did in Japan, American examples of developing hydroelectric power were mentioned during political debates. Those involved in the development of northern Finland also visited the TVA sites in the late 1940s. Ideas resembling the TVA were promoted by the Agrarian League in cooperation with the Social Democrats (Salo \& Lackman, 1998; Sippola, 2010; Mäntylä, 2016). Therefore, it is worth paying attention to the agrarian parties, which were strong in Hokkaido during the first decade after the war.

The various farmers' parties that emphasised cooperative principles in their political agenda and relied heavily on the support of agricultural interest groups did not rise to be major power holders in national politics. However, they polled exceptionally well in Hokkaido. Eventually, after almost a decade of continuous organisational flux, the Hokkaido-based agricultural parties fell away and most of their traditional supporters began to vote for Socialist Party candidates. Despite the early signs of cooperation between the socialists and the farmers' parties, they were also competing against each other. The most visible contest took place in 1951, when Governor Tanaka ran successfully for re-election against Torizō Kurosawa, who was one of the father figures of the Cooperative Party movement and dairy industry in Hokkaido (Saunavaara, 2015). Kurosawa referred to the TVA during his campaign as an inspiring foreign model for regional development and Prime Minister Shigeru Yoshida envisioned a plan for Hokkaido that would not be surpassed by even the TVA when he spoke on behalf of Kurosawa, the candidate that was also supported by the 
conservative parties (Okuda, 1956; Hiraku, 2011). However, other signs of interest in the TVA on the part of the farmers' parties have not been found.

The results of the TVA boom in the late 1940s and early 1950s can be approached from various angles. The name of the model, described even in children's books and school textbooks, was widely known. David E. Lilienthal, one of the leaders appointed to the three-person board overseeing the TVA, became a minor celebrity, and the Japanese translation of his book TVA: Democracy on the March sold well. Borrowing Dinmore's words, the TVA became a buzzword in Japanese discourse for socioeconomic progress through state-guided, comprehensive hydrologic management. Furthermore, the TVA functioned as a model for public corporations like the Nippon Telegraph and Telephone Company (NTT), a state-owned monopoly of the telecommunication sector, in the early 1950s. However, with the actual implementation of TVA ideas, the comprehensive development of national land essentially became synonymous with the construction of large dams. When Dinmore describes the defeat of the TVA principles by the large dam projects, which overlooked the needs of local farmers in favour of supplying electricity and water to urban industrial areas and industry, he does not pay attention to the only part of Japan where comprehensive development plans had already been drafted and implemented in the early 1950s (Anchordoguy, 2005; Dinmore, 2013). Although the cabinet only decided on the first Comprehensive National Development Plan in 1962, the first Hokkaido Comprehensive Development Plan covered the period from 1952 to 1961. Tokyo's TVA experts also lacked an interest in and knowledge of Hokkaido. When, for example, Hiromi Arisawa (1951) wrote a lengthy article about comprehensive regional development and the TVA in November 1951, he did not mention the ongoing process on Japan's northernmost island.

Akio Takahashi (1982) called the Takadomari Dam (completed in November 1953) the TVA of the Tanaka administration. This was the first multipurpose dam in Hokkaido that was designed from the perspective of both electric power generation and agricultural water management. Nevertheless, the First Hokkaido Comprehensive Development Plan (divided into two consecutive five-year phases covering the years 19521956 and 1957-1961) is the most important source when searching for traces of the TVA in early post-war Hokkaido. The plan - a relatively short document listing projects paving the way for the development of industry and agriculture and an increase in population - does not mention the TVA. However, it places great importance on the development of electric power, mainly hydroelectric power (Hokkaido Development Agency, 1951). Although the enthusiasm to build dams in Hokkaido from the 1950s onward may have reflected a growing awareness of their role in regional development, it was also motivated by the lack of electricity that complicated everyday life and the construction of new industry. Furthermore, the passing of the Electric Power Development Law in 1952 enabled the establishment of a government-financed organ, the Electric Power Development Corporation, which also began to construct dams in Hokkaido (Jones, 1958; Hokkaidō Doboku Gijutsukai, 2007).

The results of Hokkaido's comprehensive development were discussed critically during the second half of the 1950s. This discussion reflected the overly optimistic expectations based on plans that often lacked realistic funding schemes as well as the pent-up dissatisfaction with the structures of Hokkaido's development (Yamazaki, 2006; Koiso \& Yamazaki, 2007; Kobayashi, 2010). One of the main stimuli for this discussion was an essay by Ukichirō Nakaya, a professor at Hokkaido University, which was published in the journal Bungei Shunju in April 1957. While criticising the conduct of the policy and suggesting more appropriate ways to proceed, Nakaya referred to the TVA, which had once been popular in Japan. For Nakaya, the TVA was a model of successful regional development in which questions of leadership and responsibility were clear. In the case of the TVA, the leaders understood the local circumstances, lived in the region and devoted themselves to the work (Nakaya, 2001; Imamatsu, 2006).

\section{Adopting the Growth Pole Model as a part of the comprehensive national development policy}

The theories of regional economic divergence or unbalanced regional growth began to challenge the ideas of convergence and long-term constant per capita income growth in the 1950s. These arguments were supported by empirical evidence showing that not all regions were conforming to the predictions of the neoclassical growth models. When Gunnar Myrdal wrote about cumulative causation, he directed attention to the advantageous position enjoyed by the first industrialised regions. $\mathrm{He}$ argued that, although underdeveloped regions might benefit from growth in developed regions through the diffusion of innovation and growing export markets, their position would be challenged by the flow of capital and labour into developed regions. François Perroux's views concerning the stimulating role of the centres for the development of the entire economic system formed the basis for most growth pole theories. Although Perroux originally denied that abstract economic space could correspond to a geographic area such as a city or region, his ideas were further developed and placed in geographic space. 
When Albert O. Hirschman discussed polarised development, he emphasised the benefits of both the growing region and the surrounding less-developed region. He agreed that the developed region could purchase the products of the lagging region and offer employment. At the same time, he did not close his eyes to the possibility of developments unfavourable to the lagging region caused by growing competition. Hirschman believed that the favourable effects trickling down from the growing centre would outweigh negative polarisation effects, which could be controlled and reduced through the enactment of new economic policies (Parr, 1999; Dawkins, 2003; Zarycki, 2007).

Japan was one of the countries that adopted the Growth Pole Strategy as the guiding principle for regional planning in the 1960s and 1970s. The Comprehensive National Development Plan that was approved by the cabinet on 5 October 1962 was a major instrument incorporating the Growth Pole Model into Japanese regional development schemes. The plan emphasised the development of certain selected key regions that were considered to be potential engines of economic growth. The New Industrial City Construction Promotion Law enacted in 1962 and the Law on the Promotion of the Development of Special Regions for Industrial Development enacted in 1964 furnished the legal foundation for implementing these policy measures (Yamazaki, 2006; Koiso \& Yamazaki, 2007).

The drafting of the Comprehensive National Development Plan was a major component of, but not the only driver behind, the evolution of the policy-making process in the late 1950s and early 1960s. Socialist Governor Tanaka was replaced by Kingo Machimura, representing the ruling Liberal Democratic Party (LDP), in the 1959 gubernatorial election. This change had a great influence on cooperative relations between the Hokkaido Government, the HDA, the HDB and the central government. At the same time, various regional development laws that concentrated on other regions that were lagging behind were enacted. In this kind of situation, the Hokkaido Government and the HDA, which worked to preserve the existing Hokkaido development system, agreed that industrialisation formed the basis of Hokkaido's future contribution to the national economy. The second five-year term of the First Comprehensive Plan already aimed at promoting industries utilising Hokkaido's natural resources and raw materials. The Second Hokkaido Comprehensive Development Plan, approved in a cabinet meeting in July 1962 and implemented from 1963 onward, emphasised Hokkaido's ability to encourage the heavy chemical industry to move away from metropolitan areas in particular because these were crowded and lacked the space needed for industrial facilities (Yamazaki, 2006; Sasaki, 2015).
Central Hokkaido, consisting of the greater Sapporo area and the city of Tomakomai, was designated one of the new industrial cities in April 1964; the total number of such cities rose to fifteen in 1966. Prefectures competed strongly against each other, and eventually six special regions for industrial development were designated to diminish the disappointment of those prefectures that were not hosting any of the designated new industrial cities (Gu, 1997; Masuda, 2006). The construction of the Tomakomai Coastal Industrial Zone was the most visible project initiated in central Hokkaido. It was expected to have national significance and it was also a natural continuation of the construction of the new harbour in Tomakomai, which had been put into service in 1963 (Imamatsu, 2006).

The drafting of the Third Comprehensive Hokkaido Development Plan (approved by the cabinet in 1970 and covering the period 1971-1981) began in 1967 and had great influence on the making of the New Comprehensive National Development Plan, which was approved by the cabinet in 1969 . These parallel processes sparked debates concerning the role of a Hokkaido-specific development scheme vis-à-vis new comprehensive national planning. The Economic Planning Agency, for example, promoted a uniform national policy with three factors in mind. In addition to a desire to unify the administrative and legislative framework for development policies in all parts of Japan, it also found the unified model important from the standpoint of the large-scale development projects described in the new national plan. Finally, the unified national policy was also found necessary to secure the international competitiveness of the Japanese economy. These ideas caused anxiety in Hokkaido. Therefore, the HDA, supported by the Hokkaido Government and Hokkaido Assembly, insisted that development in Hokkaido have its own legal basis, in contrast to comprehensive national development. Similarly, it argued that the Hokkaido Comprehensive Development Plan, not the New Comprehensive National Plan, was the appropriate forum to describe the concrete plans for the development of Hokkaido (Yamazaki, 2006).

When the planning for the Third Comprehensive Hokkaido Development Plan began, the Hokkaido Government expressed its satisfaction with the achievements of the second plan. The various municipalities' lessening interest in attempts to attract new industries did not detract from the level of satisfaction. The representatives of the Socialist Party argued in the Hokkaido Assembly that the Growth Pole Strategy had led to the concentration of population and industry in cities, the depopulation of agricultural villages and disparity between regions. The representative of the Hokkaido government contradicted these claims and argued that utilising the Growth Pole System had lessened regional disparities and the migration to cities in Hokkaido had prevented outflow to other regions. 
Furthermore, it had helped in the building of relations between primary and secondary industries. The documents prepared by the Hokkaido Government to evaluate the achievements of the second plan also showed that central Hokkaido performed well among the new industrial cities as far as population growth, attracting new companies and developing of factory sites were concerned. An important concession was made when the Hokkaido Comprehensive Development Committee stated that efforts to improve people's everyday lives was given less focus than the promotion of industry, the role of which had been overemphasised in previous plans (Yamazaki, 2006).

The New Comprehensive National Development Plan continued to emphasise the importance of large-scale development projects that would secure the international competitiveness of Japan. Furthermore, a clear division of labour between regions that offered development possibilities was considered important. The plan also designated a small number of areas that were expected to host huge new industrial zones. In the case of Hokkaido, special emphasis was placed on the east and on the shores of the Pacific Ocean. In practice, this designation led to the development of the Yüfutsu Plain east of Tomakomai. Eventually, attempts aiming at the transfer of heavy chemical industry from overpopulated industrial regions to Hokkaido and the development of the Tomakomai Eastern Industrial Area came to occupy a central position in Hokkaido's development policy in the 1970s (Imamatsu, 2006; Masuda, 2006; Yamazaki, 2006; Koiso \& Yamazaki, 2007).

The presence of the Growth Pole Model in Hokkaido was obvious. However, discussions concerning its foreignness are less visible. When Yokoi Tamotsu (1965), the deputy chief secretary of the HDB, wrote about growth poles and the comprehensive development of Hokkaido, he made no reference to the foreign origin of the model. He demystified the new concept by describing it simply as a policy instrument aimed at the development of cities and surrounding areas. Therefore, it was not a major deviation from an already century-old tradition. The lack of reference to exogenous origins is most likely because the concept of growth poles was introduced to Hokkaido's development scheme as originating from the Comprehensive National Development Plan. The nationalisation or domestication of the concept was part of drafting the national plan. Hiroyoshi Sano (2012) offers a description of how a small group of people drafted the plan within a short period of time and under significant political pressure.

Masao Kitamura, a regional development specialist that worked for the Economic Planning Agency, cut short his visit to the John Hopkins University in the spring of 1961 and played a crucial role in this process. The great haste was due to the linkage between the Comprehensive National Development Plan and the famous Income Doubling Plan of Hayato Ikeda's Cabinet. The drafting of the latter was not progressing smoothly because of criticism expressed by the diet members in Japan's less-developed regions, who usually represented the governing LDP. Thus, the former needed to be adopted swiftly to still these critical voices. A rough draft of the Comprehensive National Development Plan that introduced the Growth Pole Strategy was ready in July 1961, just three months after Kitamura's return and the beginning of the actual drafting. During the process, Kitamura introduced the ideas of Perroux and Hirschman to regional development bureaucrats. While pondering how the growth poles could be set up, Kitamura leaned on ideas put forth by Leo $\mathrm{H}$. Klaassen, a Dutch scholar of urban demography. This haste led to a situation in which the Growth Pole Strategy became accepted when it was still in very abstract form. Kitamura removed within a year from leadership of the plan, and a group of policymakers and scholars continued the study. When they finally agreed that the Growth Pole Strategy was more about the creation of cities than the disposition of industry, they lacked the capability to impact the content of the policy.

Discussions regarding growth poles began in the Nordic countries during the 1960s. The rapid change in the economic structure and the shift in the demand for labour from primary production to industry and services had created great challenges, especially in the northern regions of Norway, Sweden and Finland. These regions had smaller population centres than urbanised areas in the southern parts of these countries, they lacked industry and a developed financial sector, and they suffered from a significant outflow of population. When policymakers sought a spatial policy that could stimulate the economic development of the backward regions, the growth centre policies emerged. This was not least because similar kinds of policies had already been introduced in other parts of Europe (Erikson \& Westin, 2013).

As Martin Erikson and Lars Westin (2013) pointed out, the two reports produced by the officials, experts and scholars within the European Free Trade Association (EFTA) and published in 1968 and 1970 presented the Nordic countries with a set of ideas regarding the growth centre policy. Although the decision of the EFTA working group to concentrate specifically on growth centre policy had been proposed by the Norwegian government and parts of the reports written by Norwegian experts, the process of integrating this exogenous concept into national institutions and regional development policies turned out to be a complex one. In the end, Norway did not follow the recommendations of these reports. Many of the selected growth centres were far below the threshold 
of thirty thousand inhabitants introduced in the first report and the growth centres identified differed from the designated locations of the industrial estates and went against the recommendations of the second report. The policymakers in Sweden and Finland were equally inclined to formulate growth centre policies that fit into local political realms even if they went against the EFTA working group's recommendations.

Both in Japan and in the Nordic countries it was easier to accept the Growth Pole Model as an abstract model for regional development than to reach political consensus concerning the number, size and location of the designated growth poles. Because the designations were outcomes of political debates and compromises, it is doubtful whether the designated regions demonstrated the characteristics attached to the so-called natural or spontaneous growth poles (see Parr, 1999). Furthermore, when the policymaking processes in the Nordic context are compared to Hokkaido, the relatively early incorporation of the growth poles into Japanese regional development policies and the rapidity of the process become clear. The processes through which the growth pole policies came into being in Norway and Finland demonstrate the relationship between regional policies and political competition, and compromises between the social democratic and centre parties, which were traditionally agricultural parties (Sippola, 2010; Erikson \& Westin, 2013). Meanwhile, the LDP's continuous rule ${ }^{[1]}$ of Japan made this almost an intra-party affair, although the position of the Socialist Party was especially strong in Hokkaido. Interestingly, Hokkaido's socialists seem to have been critical of the policy that was promoted by social democrats in the Nordic countries, where the urban population was more likely to vote for social democratic parties than the rural population. This difference may reflect the socialists' wide support-base among Hokkaido's farmers or the party's role in the opposition. Finally, the role that the EFTA reports played in Nordic countries highlights the lack of participation on the part of international governmental organisations in Hokkaido.

The agents that struggled to secure the continuance of the special Hokkaido development system had little scope to prevent the incorporation of the Growth Pole Model into Hokkaido's development policy. However, this process could not be described as forced policy transfer because it appears that there were no compelling reasons to oppose this change. However, the application of the Growth Pole Strategy supports Kwon's (2009) argument that policy transfer in developmental states was rarely a response to social demands and was often introduced from the top down as part of an effort to modernise in general and industrialise in particular.

\section{Introducing industrial clusters based on demands from below}

Although the circumstances affecting the development of Hokkaido changed, the objectives and content of the policies also gradually evolved. It can be argued that policymakers could have been faster to react, for example, to the collapse of the Bretton Woods system in 1971, ${ }^{[2]}$ the two oil crises in the 1970s or the evaluation of the yen based on the Plaza Accord in 1985. All of these caused changes in Japan's overall industrial structure and made the possibility of attracting heavy chemical industry into Hokkaido less likely. However, the Fourth Hokkaido Comprehensive Development Plan (1978-1987) had already introduced new approaches and placed emphasis on the natural environment, human welfare and local participation. This kind of change in Hokkaido was again bound to drafting the new Comprehensive National Development Plan (Yamazaki, 2006; Koiso \& Yamazaki, 2007). The deep, post-bubble recession of the 1990s also left its mark on Hokkaido's development policy. At a time of great concern about the future funding of development projects and just when many household names in Hokkaido were facing serious problems or bankruptcy (e.g., Hokkaido Takushoku Ginko, the largest bank in Hokkaido, collapsed in the autumn of 1997), there emerged a new catchphrase, the industrial cluster.

There are various interpretations of a cluster. In general, clustering refers to the concentration of industries and companies in a specific geographic area and to their interrelationships. The theoretical foundations of clustering suggest that domestic, regional or local rivalry and discriminating local demand foster innovation and prepare enterprise for global markets. Meanwhile, the great number of firms in close proximity, the high proportion of small and very small firms, dense social and economic networks, a blend of competition and cooperation between firms, the rapid and mainly informal diffusion of information and ideas, adaptability and flexibility have all been identified as features typical of industrial clusters (Dawkins, 2003; Lundmark \& Petterson, 2012; Piperopolous, 2012; Swords, 2013). Although the theoretical discussion concerning industrial clusters has been conducted by various parties, Michael Porter, who published The competitive advantage of nations (1990), has been credited with introducing the terminology to a wider audience. The name of this American business economist at Harvard Business School was also known in Hokkaido, and Silicon Valley was an example of a successful industrial clustering process known throughout the world. Jon Swords (2013) offers a fascinating analysis that explains the 
popularity of Porter's ideas among policymakers, describes the role of regional development experts in spreading these ideas and notes the legitimacy gained by clusters when incorporated into the policies of the OECD and the European Union, for example. However, the new input into the discussion about regional development was neither imported from the United States nor imposed by international organisations. Rather, Hokkaido's initiatives benefited from lessons drawn from the Nordic countries.

Although there is a clear temporal correlation between developments in Hokkaido and the nationwide shift from the "technopolis policy" of the 1980s, implemented by the Ministry of Trade and Industry, to cluster policies with a stronger local character at the end of 1990s (Kitagawa, 2008), the cluster initiatives have been described as an extraordinary bottom-up contribution to Hokkaido's development. In addition to national policy instruments, such as the 1955 Science and Technology Basic Law and the consecutive Science and Technology Basic Plans, the emergence of these initiatives owed much to the activities of local interest groups and influential individuals. The Hokkaido Electric Power Company (HEPCO) and its chairman, Kazuo Toda, who was also the chairman of the Hokkaido Economic Federation, played an important role. In fact, Toda personified the various cluster initiatives in Hokkaido to the extent that they become dependent on his presence and contribution (Mäki, 1997; Iguchi, 1998; Koiso, 2016). The HDA's readiness to draw lessons from regional development policies carried out in other countries should not be forgotten either. In 1993, the agency held a conference that placed special emphasis on the development of Scotland. A second conference in 1995 focused on Sweden. The research conducted also took into consideration regional development and industrial policies in Finland. This was due to the interest shown by the Hokkaido business community in Finnish industrial cluster strategies (Koiso, 1995; Koiso \& Yamazaki, 2007).

The Oulu region in central Finland soon emerged as a benchmark case that was considered worthy of study. The HEPCO delegations visited various sites in the Oulu region during the first half of the 1990s, and the first delegation from Oulu representing the city and regional agents visited Hokkaido in February 1995. The interest shown by Hokkaido's agents was not unique; the Oulu phenomenon was attracting attention internationally in the 1990s. The Oulu region had witnessed remarkable growth in the information and communication technology (ICT) industries. The development that culminated in Oulu being considered one of the largest wireless telecommunication technology research and development centres worldwide had its roots in the 1980s. Nokia, the engine behind the growth, started its mobile and wireless communication product development towards the end of the decade (Oinas-Kukkonen et al., 2009; Arokylä, 2012; Salo, 2014; Simonen et al., 2016).

Although the Oulu ICT cluster in general - and Technopolis (the first technology park in the Nordic countries, established in 1982) in particular - were soon to emerge as the main objects of interest, district heating systems drew attention in the early and mid-1990s. Furthermore, Toda mentions the Finnish forest industry cluster as an early model for the creation of industrial clusters in Hokkaido (Mäki, 1997; Koiso, 1999). The emphasised role of the ICT may reflect visitors' interests and also the development that took place in Oulu. When Technopolis was founded, the founding members were the City of Oulu, the University of Oulu, the National Development Funding Foundation and twenty-eight private companies. Different industries were broadly represented among these enterprises, from paper and pulp, to basic and productbased metal industries, construction, energy, infrastructure and media industries. Only one firm represented telecommunications. This broad spread soon grew narrower. The driver was the rapid development of wireless mobile technologies (Simonen et al., 2016).

The relations between Hokkaido and the Nordic countries strengthened from 1996 onwards, and delegations representing HEPCO and other companies, the HDA, Hokkaido Prefecture and various municipalities, local universities and various newspapers kept flowing, particularly to Oulu, which was described as the Silicon Valley of the north (Koizumi, 1997a, 1997b, 1997c; Yasunaga, 1997a, 1997b; Kawasaki, 1997, 1998; Yamagoshi, 1999). These efforts led to two types of initiatives in Hokkaido. In addition to the different programmes in the main urban areas, the idea of industrial clusters and local cooperation was put into practice in various rural or remote communities. In 2000, a year before the Ministry of Economy, Trade and Industry (METI) initiated its Industrial Cluster Program under the Super Cluster Promotion Strategy (Woolgar, 2008), twenty regional cluster investigation and promotion organisations had already been established in various parts of Hokkaido. The operations of these organisations often aimed at increased efficiency in producing and marketing products utilising the region's natural resources and outputs of the primary sector (Koiso, 1999; Ōhashi, 2000). This kind of rural or non-metropolitan approach to clusters can be emphasised as a special characteristic of Hokkaido-based initiatives because cluster theory and policy were usually oriented towards urban areas and new industries, as in Sweden, for example (Lundmark \& Petterson, 2012). However, the high-tech companies that were expected to gain from closer cooperation between academia, industry and government also had a crucial role to play. 
Table 1: Major institutions and instruments supporting the creation of industrial clusters in Hokkaido.

\begin{tabular}{ll}
\hline June 1986 & Hokkaido Regional Technology Advancement Centre (HOKTAC) \\
\hline July 1993 & Hokkaido Foundation for the Promotion of Science, Industry and Technology \\
\hline Feb. 1996 & $\begin{array}{l}\text { Regional Industry Policy Research Group (founded in February 1995), renamed Hokkaido Industrial Cluster Creation } \\
\text { Research Group }\end{array}$ \\
\hline Aug. 1996 & Toward Self-Sustaining Hokkaido Economy Vision by Hokkaido Industrial Cluster Creation Research Group \\
\hline Mag 1997 & High-Technology Research Centre established within Hokkaido University \\
\hline Dec. 1997 & Toward the Creation of Hokkaido Industrial Clusters (midterm report) \\
\hline Apr. 1998 & Cluster Project Department established within HOKTAC \\
\hline Feb. 2000 & $\begin{array}{l}\text { Hokkaido Industry-Academia-Government Collaboration Centre established within Hokkaido University (KORABO Ho- } \\
\text { kkaido) }\end{array}$ \\
\hline July 2001 & $\begin{array}{l}\text { HOKTAC and the Hokkaido Foundation for the Promotion of Science, Industry and Technology merge into the Northern } \\
\text { Advancement Centre for Science and Technology (NOASTEC) }\end{array}$ \\
\hline 2002 & Establishment of Creative Research Initiative Sousei (CRIS) \\
\hline Apr. 2003 & Hokkaido University Research and Business Park Promotion Committee \\
\hline Apr. 2007 & $\begin{array}{l}\text { Hokkaido University Research and Business Park Promotion Committee secretariat switched from the Hokkaido Econo- } \\
\text { mic Federation to NOASTEC }\end{array}$ \\
\hline
\end{tabular}

Source: Ōhashi (2000), Internet 1, Internet 2.

The roots of technology park initiatives in Hokkaido precede the late 1990s; regional and city policies that reflected national trends favouring the promotion and concentration of knowledge-intensive high-tech companies in peripheral regions had already emerged in the 1980s (Yamada, 2004; Kitagawa, 2008). However, the discussion on industrial clusters contributed significantly to a greater interest and belief in ICT-centred regional development, which took an institutional form through various organisations and strategies. Yüji Ōhashi (2000) analysed Hokkaido-based cluster creation activities and dated the beginning of the movement to the establishment of the Hokkaido Industrial Cluster Creation Research Group in 1996. As Table 1 shows, this was followed by the announcement of an action plan setting out the direction and the objectives and paving the way for the establishment of a unit to implement the plan, namely the Cluster Project Department within the Hokkaido Regional Technology Advancement Centre.

The promotion of cooperation between business, science and government was enhanced through the establishment of the Hokkaido University Research and Business Park Promotion Committee in 2003. Eventually, the study of the Oulu ICT cluster culminated in two joint symposia held in Sapporo and Oulu in March 2004 and September 2005. The Sapporo event was called Regional Cooperation for Technology-Based Economic Development. The background of the speakers representing, for example, Hokkaido University, the City of Sapporo, the Hokkaido Government, the Japan Science and Technology Agency, the Hokkaido Industrial Research Institute, NOASTEC and the Hokkaido Economic Federation - describes well the nature of the agents involved in Hokkaido's ICT cluster initiatives. ${ }^{[3]}$ The absence of the HDA is explained by the fact that it had been amalgamated into the Ministry of Land, Infrastructure, Transport and Tourism in January 2001.

The content of the Sixth Hokkaido Comprehensive Development Plan (1998-2007) demonstrates the institutionalisation of industrial clusters within government-approved policy. The Project for the Creation of Hokkaido Industry Clusters is introduced as one of the methods of accomplishing the overall aims of the plan, which also includes both sides of the cluster initiatives introduced above. It makes references to clusters that bring together the local primary sector and industries in rural Hokkaido and emphasises the cooperation between universities and private enterprises bound to the ICT-related development in central Hokkaido. At the same time, the Hokkaido-based cluster projects received significant funding from the national Industrial and Knowledge Cluster Programmes implemented by the METI and the Ministry of Education, Culture, Sports, Science and Technology (Woolgar, 2008). However, the Seventh Hokkaido Comprehensive Development Plan, promoted from 2008 onwards, shows waning enthusiasm for industrial clusters. The concept is mentioned only twice when referring to the achievements of the previous plan (Hokkaido Development Agency, 1998; Ministry of Land, Infrastructure, Transport and Tourism, 2008). Although endogenous reasons, such as the waning influence of Kazuo Toda, might explain this kind of change, it can also be pointed out that in the mid-2000s cluster policies were also peaking in other spatial contexts (Swords, 2013). 
Table 2: Incorporation of international development strategies into Hokkaido's development policy.

\begin{tabular}{|c|c|c|c|}
\hline $\begin{array}{l}\text { Development strategy } \\
\text { (timing) }\end{array}$ & TVA (late 1940s and early1950s) & Growth Poles (1960s and 1970s) & Clusters (1990s and early 2000s) \\
\hline Source or origin of inspiration & $\begin{array}{l}\text { United States, TVA, David E. } \\
\text { Lilienthal }\end{array}$ & $\begin{array}{l}\text { Comprehensive National } \\
\text { Development Plan }\end{array}$ & Oulu region, Nordic countries \\
\hline National context & $\begin{array}{l}\text { Allied occupation, post-war re- } \\
\text { construction }\end{array}$ & $\begin{array}{l}\text { Beginning of comprehensive } \\
\text { national planning }\end{array}$ & $\begin{array}{l}\text { Shift from the technopolis policy, } \\
\text { burst of the bubble economy }\end{array}$ \\
\hline Hokkaido context & $\begin{array}{l}\text { Reconstruction, First Hokkaido } \\
\text { Plan }\end{array}$ & $\begin{array}{l}\text { Second and Third Hokkaido } \\
\text { Comprehensive Plans }\end{array}$ & $\begin{array}{l}\text { Concern about funding deve- } \\
\text { lopment projects, bankruptcies }\end{array}$ \\
\hline $\begin{array}{l}\text { Local promoters of new deve- } \\
\text { lopment strategies }\end{array}$ & $\begin{array}{l}\text { Governor Toshifumi Tanaka (left- } \\
\text {-wing of the political spectrum) }\end{array}$ & - & $\begin{array}{l}\text { Kazuo Toda (HEPCO, Hokkaido } \\
\text { Economic Federation) }\end{array}$ \\
\hline Short-term outcome & $\begin{array}{l}\text { Public recognition, not a part of } \\
\text { the First Comprehensive Hokkai- } \\
\text { do Development Plan but resem- } \\
\text { bling infrastructure projects }\end{array}$ & $\begin{array}{l}\text { Growth Poles incorporated into } \\
\text { the Hokkaido Comprehensive } \\
\text { Development Plans }\end{array}$ & $\begin{array}{l}\text { Organisational development, } \\
\text { clusters become part of the Sixth } \\
\text { Comprehensive Hokkaido Deve- } \\
\text { lopment Plan }\end{array}$ \\
\hline
\end{tabular}

\section{Conclusion}

When considering what may be the take-home messages for current policymakers, one can begin by stating that this study has not revealed any institutional or cultural filters that would have caused Japanese policymakers not to use information and experience from abroad. Rather than possessing the kind of features observed by Dolowitz and Dale Medearis (2009) in US policymakers at the beginning of the twenty-first century, a readiness to incorporate exogenous models has remained throughout the post-war period. It should, however, be pointed out that the readiness observed is not exceptional. On the contrary, many previous studies have concluded that regional development agents in different parts of the world have frequently ended up designing similar kinds of development strategies (Barca et al., 2012). Although a continuation of this kind of openness can be hoped for, it is worth remembering the point made by Linda Lundmark and Örjan Petterson (2012) about the importance of recognising examples suitable for the development of sparsely populated areas.

This research also shows the great variety of agents involved in policy transfer processes. Through the three cases representing different post-war decades, it can be seen that not only politicians and bureaucrats (at the national and regional levels) but also representatives of various interest groups and scholars have participated in these processes. Hence this study may encourage current actors to express their opinions concerning existing issues or to place new topics on the political agenda.

Although the most optimistic objectives of the industrial cluster initiatives, for example, may not have been achieved, the 1990s and early 2000s can still be considered an example of a successful bottom-up type of policy initiative. Clusters were put onto the agenda but, as also learned through other case studies, their incubation proved difficult (Bresnahan \& Gambardella, 2005; Yamamoto, 2017). The direct involvement of foreign voices in policymaking has been extremely limited except during the late 1940s and early 1950s, when Japan was still under foreign occupation. However, it can be concluded that whatever was transferred in relation to the TVA was not part of a forced transfer under pressure exerted by foreign occupation.

This research also provides further empirical evidence backing the notion that policy transfers, attempted or completed, do not differ from other policy-making processes and are often based on incomplete or incorrect information. Theoretical literature also emphasises that policy transfer is not an all-ornothing process. The degree of transfer varies from copying and emulation to the blending of different policies or inspiration, where policy can simply inspire change without following the content of the original policy. It has also been hinted that different kinds of agents might be inclined towards different degrees of transfer (Dolowitz \& Marsh, 2000). The current study does not, however, support assumptions according to which politicians would be looking for a quick fix through emulation, whereas bureaucrats would be more interested in a mélange. Although the TVA seems to have appeared to its most ardent supporters as an ideal model that should be copied to the letter, these hopes were not realised. The interpretation of the original model and its adaptation to local circumstances plays a significant role in all of the processes analysed.

As shown in Table 2, this research demonstrates the diversity of origins that agents involved in policy transfer can draw lessons from. In the case of the TVA, the policy model was taken directly from the place of origin, and discussions at every level paid attention to the foreign nature of the model. The 
incorporation of the Growth Pole Strategy into Hokkaido's development scheme was a totally different process that concentrated on the regionalisation of the national policy model, which just happened to have exogenous origins. In the case of industrial clusters, the origins of the model lay elsewhere, but the drafting of policy measures gained momentum only after initiatives were taken by local actors interested in benchmarking a peripheral region seen as corresponding well to the conditions existing in Hokkaido.

Finally, Hokkaido's post-war development policy serves as a reminder of the need for caution when labelling states or regions as givers or takers. Although Hokkaido's development policy took elements from various sources (which had often taken these ideas from elsewhere), it also acted as a model for other regions. For example, Hokkaido was studied in the mid-1980s, when the development policies concerning southern Italy were re-evaluated and redirected. Furthermore, Hokkaido's development policy has also served as a model for Japanese development aid policies (Koiso, 2005; Koiso \& Yamazaki, 2007).

Juha Saunavaara

Hokkaido University, Arctic Research Center, Sapporo, Japan

E-mail: juha.saunavaara@arc.hokudai.ac.jp

\section{Notes}

${ }^{[1]}$ The LDP was the ruling party between 1955 and 1993, when it was ousted by a coalition cabinet. The LDP returned to the cabinet in 1994 and regained the premiership in 1996. The LDP was also in opposition between 2009 and 2012.

${ }^{[2]}$ The Bretton Woods system was based on the US dollar's fixed value against gold and on fixed exchange rates. The system was gradually broken after the dollar's convertibility to gold was suspended in 1971. As a result, the major currencies had begun to float against each other by March 1973.

${ }^{[3]}$ The programmes of these events can be found in the archives of the University of Oulu: Oulun yliopiston rehtorin arkisto. Kansainväliset yhteydet - Japani, Kiina, Korea 1993-2014. Hi: 10.

\section{Acknowledgments}

This article was written with the aid of the Academy of Finland Grant (Japan: researcher mobility). The author would like to thank Lars Westin and two anonymous reviewers for their comments on the manuscript.

\section{References}

Allison, G. \& Zelikow, P. (1999) Essence of decision. Explaining the Cuban missile crisis. 2nd edition. New York, Addison Wesley Longman.

Anchordoguy, M. (2005) Reprogramming Japan: The high tech crisis under communitarian capitalism. Ithaca, NY, Cornell University Press.
Arisawa, H. (1951) Kokudo sōgō kaihatsu to ha nanika. Sekai, November, pp. 112-124.

Armstrong, H. \& Taylor, J. (2000) Regional economics and policy. 3rd edition. Oxford, Blackwell Publishers.

Arokylä, K. (2012) Technopolis - kertomus kasvusta. Oulu, Technopolis Oyj.

Banno, A. (2003) Hokkaidō kaihatsu kyoku to ha nanika. GHQ senryōka ni okeru nijū gyōsei no hajimari. Sapporo, Yūgen Kaisha Jurōsha.

Barca, F., McCann, P. \& Rodriguez-Pose, A. (2012) The case for regional development intervention: Place-based versus place-neutral approaches. Journal of Regional Science, 52(1), pp. 134-152. DOI: $10.1111 /$ j.1467-9787.2011.00756.x

Benson, D. \& Jordan, A. (2011) What have we learned from policy transfer research? Dolowitz and Marsh revisited. Political Studies Review, 2011(9), pp. 366-378. DOI: 10.1111/j.1478-9302.2011.00240.x

Bresnahan, T. \& Gambardella, A. (2005) Old-economy inputs for neweconomy outcomes. What have we learned. In: Bresnahan, T. \& Gambardella, A. (eds.) Building high-tech clusters - Silicon Valley and beyond, pp. 331-358. Cambridge, Cambridge University Press.

Dawkins, C. J. (2003) Regional development theory: Conceptual foundations, classic works, and recent developments. Journal of Planning Literature, 18(2), pp. 131-172. DOI: 10.1177/0885412203254706

Dinmore, E. (2013) Concrete results? The TVA and the appeal of large dams in occupation-era Japan. The Journal of Japanese Studies, 39(1), pp. 1-38. DOI: 10.1353/jjs.2013.0034

Dolowitz, D. P. \& Marsh, D. (2000) Learning from abroad: The role of policy transfer in contemporary policy-making. Governance, 13(1), pp. 5-23. DOI: 10.1111/0952-1895.00121

Dolowitz, D. P. \& Medearis, D. (2009) Considerations about the obstacles and opportunities for formalizing cross-national policy transfer to the United States: a case study about the transfer of urban environmental and planning policies from Germany. Environment and Planning C: Government and Policy, 27(4), pp. 684-697. DOI: 10.1068/c0865j

Erikson, M. \& Westin, L. (2013) Regional policy as interaction between national institutions and regional science. The Nordic growth centre policies, 1965-1980. Scandinavian Journal of History, 38(3), pp. 367-386. DOI: 10.1080/03468755.2013.805307

Gu, L. (1997) Chiiki kyoten kaihatsuron to chūgoku no keizai kaihatsu ku - chūgoku to nihon to no hikaku bunseki. Kokusai Kaihatsu Kenkyū Fōramu, 7(1), pp. 75-105.

Hiraku, T. (2011) Sengo no hokkaidō kaihatsu - taisei no seiritsu keika to chiiki kadai he no torikumi. Sapporo, Hokkaidō Shuppan Kikaku Sentaa.

Hokkaido Development Agency (1951) Hokkaidō sōgō kaihatsu keikaku (An). Tokyo.

Hokkaido Development Agency (1998) Dai 6 ki hokkaidō sōgō kaihatsu keikaku, asu no nihon wo tsukuru hokkaidō. Tokyo. Available at: http:// www.mlit.go.jp/hkb/plan.html (accessed 18 Apr. 2017).

Hokkaidō Doboku Gijutsukai Konkuriito Kenkyū linkai (2007) Hokkaidō ni okeru konkuriito damu no rekishi. Sapporo.

Iguchi, M. (1998) Economic situation of Japan and Hokkaido in 1990s. An analysis of the opaque situation and some future prospects of the 21st century. Hokkaido - Lapland News, 1998(3), pp. 1-3.

Imamatsu, E. (2006) Tomakomaikō kaihatsu (gen toma) no rekishi. In: Masuda, T., Imamatsu, E. \& Koda, K. (eds.) Naze kyojin kaihatsu ha hatan shitaka. Tomakomai higashibu kaihatsu no kenshō, pp. 17-38. Tokyo, Nihon Keizai Hyōronsha. 
Internet 1: https://www.noastec.jp/web/about/outline.html (accessed 1 Sept. 2017).

Internet 2: http://www.cris.hokudai.ac.jp/cris/rbp/en/sousei/brief03.html (accessed 1 Sept. 2017).

Internet 3: https://www.tva.gov/About-TVA/Our-History (accessed 27 Dec. 2016).

Jones, F. C. (1958) Hokkaido - its present state of development and future prospects. London, Oxford University Press.

Kawasaki, K. (1997) Hokuō to hokkaidō no sangyō kurasutaa. Jetro Sensaa, 6, pp. 39-42.

Kawasaki, K. (1998) Hokuō to hokkaidō no sangyō kurasutaa to kyōdō no Igi. NIRA Seisaku Kenkyū, 11(7), pp. 40-43.

Kitagawa, F. (2008) From technopolis, cluster to regional science policy? Japanese regional development policy 1980s-2000s. In: Koh, Y. \& Chung, W. (eds.) 2008 KDI International Conference: International experiences of regional policy and policy implications for Korea, pp. 201-231. Sejong, Korea, Korea Development Institute.

Kobayashi, Y. (2010) Hokkaidō no keizai to kaihatsu - ronten to kadai. Sapporo, Hokkaidō Daigaku Shuppankai.

Koiso, S. (1995) Hokuō no chiiki kaihatsu seisaku - suweeden, finrando no torikumi. Manuscript.

Koiso, S. (1999) Sangyō kurasutaa sōzō he no michinori. Marujunorudo - Kaihatsu kōhō, 1, pp. 7-11.

Koiso, S. (2003) Sengo hokkaidō kaihatsu gyōsei shisutemu no keisei katei. Hokkaidō kaihatsu no kiseki. Sapporo, Hokkaidō Kaihatsu Kyōkai.

Koiso, S. (2005) Shirukurōdo no kohan ni hanasake hokkaidō no keiken - ishikukuri chiiki sōgō kaihatsu keikaku chōsa jigyō. Hoppoken, 132, pp. 16-19.

Koiso, S. (2016) Interview about industrial clusters in Hokaido (interview, 20 Jul. 2016).

Koiso, S. \& Yamazaki, M. (2007) Sengo hokkaidō kaihatsu no kiseki taidan to nenpyō de furikaeru kaihatsu seisaku 1945-2006. Sapporo, Hokkaidō Kaihatsu Kyōkai.

Koizumi, M. (1997a) Daigaku-kigyō missetsu renkei ni odoroki - "hokuō no shirikonbaree" de shisatsudan. Yomiuri Shimbun (Hokkaido edition), 6 Sept. 1997.

Koizumi, M. (1997b) Jiritsu shinkō, dō no shishin ni - Hokuō Shisatsudan Ouru Shiyakusho nado Hōmon. Yomiuri Shimbun (Hokkaido edition), 7 Sept. 1997.

Koizumi, M. (1997c) Ouru shisatsu wo iken kōkan. Yomiuri Shimbun (Hokkaido edition), 8 Sept. 1997.

Kwon, H. (2009) Policy learning and transfer: The experience of the developmental state in East Asia. Policy and Politics, 37(3), pp. 409-421. DOI: $10.1332 / 030557309 \times 435817$

Lindblom, C. E. (1968) The policy-making process (= Foundations of Modern Political Science series). Englewood Cliffs, NJ, Prentice-Hall.

Lundmark, L. \& Petterson, Ö. (2012) The relevance of cluster initiatives in rural areas: Regional policy in Sweden. Urbani izziv, 23(1), pp. 42-52. DOI: 10.5379/urbani-izziv-en-2012-23-supplement-1-004

Mäki, S. (1997) Oulun ja Hokkaidon välinen alueyhteistyö 1990-luvulla, 22.10.1997. Manuscript.

Mäntylä, M. (2016) Pohjois-Suomea kehittämässä: Periferia Urho Kekkosen politiikan kohteena ja vallankäytön välineenä vuosina 1950-1981. Rovaniemi, Finland, Pohjois-Suomen Historiallinen Yhdistys.
Mason, M. M. (2012) Dominant narratives of colonial Hokkaido and imperial Japan: Envisioning the periphery and the modern nation-state. New York, Palgrave Macmillan. DOI: 10.1057/9781137330888

Masuda, T. (2006) 21 Seiki no chiiki keizai seisaku to ha - tomakomai higashibu kaihatsu wo jirei toshite. In: Masuda, T., Imamatsu, E. \& Koda, K. (eds.) Naze kyojin kaihatsu ha hatan shitaka. Tomakomai higashibu kaihatsu no kenshō, pp. 213-240. Tokyo, Nihon Keizai Hyōronsha.

Ministry of Land, Infrastructure, Transport and Tourism (2008) Chikyu kankyō jidai wo sendō suru shin hokkaidō sōgō kaihatsu keikaku. Available at: http://www.mlit.go.jp/hkb/plan.html (accessed 18 Apr. 2017).

Nakaya, U. (2001) Nakaya Ukichirō shū, Dai 8 kan. Tokyo, Iwanami Shoten.

Ōhashi, Y. (2000) Sangyō kurasutaa sōzō katsudō no genjō to kadai hokkaidō keizai no jiritsu wo jitsugen suru tame ni. Chiiki kaihatsu, 432(9), pp. 14-20.

Oinas-Kukkonen, H., Similä, J. \& Pulli, P. (2009) Main threads of ICT innovation in Oulu 1960-1990. Faravid 33, pp. 247-272.

Okuda, J. (1956) Dōsei fūunroku - sengo 10 nen. Sapporo, Sōjusha.

Parr, J. B. (1999) Growth-pole strategies in regional economic planning: A retrospective view. Part 1. Origins and advocacy. Urban Studies, 36(7), pp. 1195-1215. DOI: 10.1080/0042098993187

Pike, A., Rodriguez-Pose, A. \& Tomaney, J. (2007) What kind of local and regional development and for whom. Regional Studies, 41(9), pp. 12531269. DOI: $10.1080 / 00343400701543355$

Piperopolous, P. G. (2012) Entrepreneurship, innovation and business clusters. Farnham, UK, Gower Publishing Limited.

Porter, M. E. (1990) The competitive advantage of nations. New York, Free Press. DOI: 10.1007/978-1-349-11336-1

Salo, M. (2014) High-tech centre in the periphery: The political, economic and cultural factors behind the emergence and development of the Oulu ICT phenomenon in northern Finland. Acta Borealia: A Nordic Journal of Circumpolar Societies, 31(1), pp. 83-107. DOI: 10.1080/08003831.2014.905008

Salo, M. \& Lackman, M. (1998) Oulun yliopiston historia 1958-1993. Oulu, Oulun Yliopisto.

Sano, H. (2012) Zenkoku sōgō kaihatsu keikaku ni okeru kyoten kaihatsu kōsō ni kan suru kenkyū. Kōeki Zaidan Hōjin Nihon Toshi Keikaku Gakkai Toshi Keikaku Bunshū, 47(3), pp. 403-408.

Sasaki, T. (2015) Japan's postwar military and civil society. London, Bloomsbury.

Saunavaara, J. (2014) Postwar development of Hokkaido: The U.S. occupation authorities' local government reform in Japan. Journal of American-East Asian Relations, 21(2), pp. 134-155. DOI: $10.1163 / 18765610-02102004$

Saunavaara, J. (2015) Multilevel relations in Japanese political parties at the beginning of the post-war period: Hokkaido as a case study. Contemporary Japan, 27(2), pp. 149-168. DOI: 10.1515/cj-2015-0009

Simonen, J., Koivumäki, T., Seppänen, V., Sohlo, S. \& Svento, R. (2016) What happened to the growth? - The case of the ICT industry in Oulu, Finland. International Journal of Entrepreneurship and Small Business, 29(2), pp. 287-308. DOI: 10.1504/IJESB.2016.078704

Sippola, M. (2010) Kehitysalueista aluekehitykseen. Suomen virallisen aluepolitiikan 30 ensimmäistä vuotta 1966-1995. Helsinki, Työ- ja elinkeinoministeriön julkaisuja. Alueiden kehittäminen.

Takahashi, A. (1982): Shōgen: hokkaidō sengoshi - Tanaka dōsei to sono jidai. Saporo, Hokkaidō Shimbunsha. 
Swords, J. (2013) Michael Porter's cluster theory as a local and regional development tool: The rise and fall of cluster policy in the UK. Local Economy, 28(4), str. 369-383. DOI: 10.1177/0269094213475855

Woolgar, L. (2008) Hokkaido new industrial cluster policy (Japan). In: A review of local economic and employment development policy approaches in OECD countries, Part I: Policy audits, pp. 236-258. Paris, OECD.

Yamada, S. (2004) Jōhō - sofutowea sangyō. In: Ōnuma, M. (ed) Hokkaidō sangyō shi, pp. 307-321. Sapporo, Hokkaidō Daigaku Tosho Kankōkai.

Yamagoshi, K. (1999) Kankyō seibi de kigyō wo shien. Nihon Keizai Shimbun, 21 Jan. 1999.

Yamamoto, T. (2017) Interview about ICT infrastructure and industry in Hokkaido (interview, 27 Jan. 2017).

Yamazaki, M. (2006) Kokudo kaihatsu no jidai - sengo hokkaidō wo meguru jichi to tōchi. Tokyo, Tōkyō Daigaku Shuppankai.

Yasunaga, M. (1997a) Hokuō ni sagaru dōkeizai no saisei - [tekunoporisu] chihō de kinō. Yomiuri Shimbun, 10 Jun. 1997.

Yasunaga, M. (1997b) Shōshotai, aidea soku seihin. Yomiuri Shimbun, 12 Jun. 1997.

Yokoi, T. (1965) Hokkaidō sōgō kaihatsu to kyoten kaihatsu. Shin Toshi, 19(7), pp. 20-23.

Zarycki, T. (2007) An interdisciplinary model of centre-periphery relations: A theoretical proposition. Regional and Local Studies. Special issue, pp. 110-130. 